\title{
Evolution of e-government: Transparency, competency, and service- oriented government with Korean government 3.0
}

\author{
June-Suh Cho \\ Hankuk University of Foreign Studies, Seoul, Korea
}

\author{
Keywords \\ E-Government, transformation, transparency, competency, service-oriented government, \\ government 3.0
}

\begin{abstract}
E-government is increasingly being implemented in all areas of government administration. It is increasing efficiency and transparency and bringing convenience and safety to citizens' lives, and consequently improving the quality of life. E-government is a transformation of government processes, transactions, and policy making and implementation that are efficiently carried out through information and communication technologies to provide better and efficient services to the citizens while reducing waste and corruption and increasing accountability, transparency, and trust.

This paper discusses the efforts of Korean government to transforming with transparency, competency, service-oriented government.
\end{abstract}

Corresponding author: June-Suh Cho

Email address for corresponding author: jscho@hufs.ac.kr

First submission received: 8th March 2017

Revised submission received: 26th April 2017

Accepted: 28th July 2017

Acknowledgement

This work was supported by Hankuk University of Foreign Studies Research Fund of 2017

\section{Introduction}

E-government has achieved significant improvements through the deployment of many innovative applications (Gronlund \& Horan, 2005; Lee et al., 2005). Citizens use government web sites as central points of access to government information and services across different agencies via Internet or Mobile access.

Transformation of government processes, transactions, and policy making and implementation that are efficiently carried out through ICTs. Through ICT, new forms of collaboration and interorganizational public service networks become feasible, making it possible to carry out the public sector's tasks more efficiently and effectively. Also, ICTs provide better and efficient services to the citizens while reducing waste and corruption and increasing accountability, transparency, and trust.

In this paper, we discuss about transparency, competency, and service-oriented government with Korean government case. Inspite of successful implementation, Korean government need more transformation of government. Despite the advanced E-Government services and infrastructure, egovernment has not changed the way government works much. Also, innovative programs through ICT should contribute to change government culture and the way officials working. They must consider how to measure the performance or accomplishments of the results. They are also failed to integrate online services of each agency due to the lack of information sharing in government. Furthermore, they need to provide one-stop, customized service for each people to promote wellbeing of Korean.

\section{Background}

Certainly, the most compelling political news about Web 2.0 has been the way that social networking has revolutionised the art of political campaigning. But the most enduring political 
implications of Web 2.0 may lie in what democratic governments seek to achieve in their efforts to engage users in the mundane daily processes of governance. Administrative agencies, particularly in the bureaucratic and industrial age, are finally changing as governments reinvent themselves for the information age. One essential part of this transformation to Government 2.0 is the recognition that the social media enable governments to invite citizens, as democratic watchdogs and collaborators as well as creative do-it-yourself forces, into the administration of government.

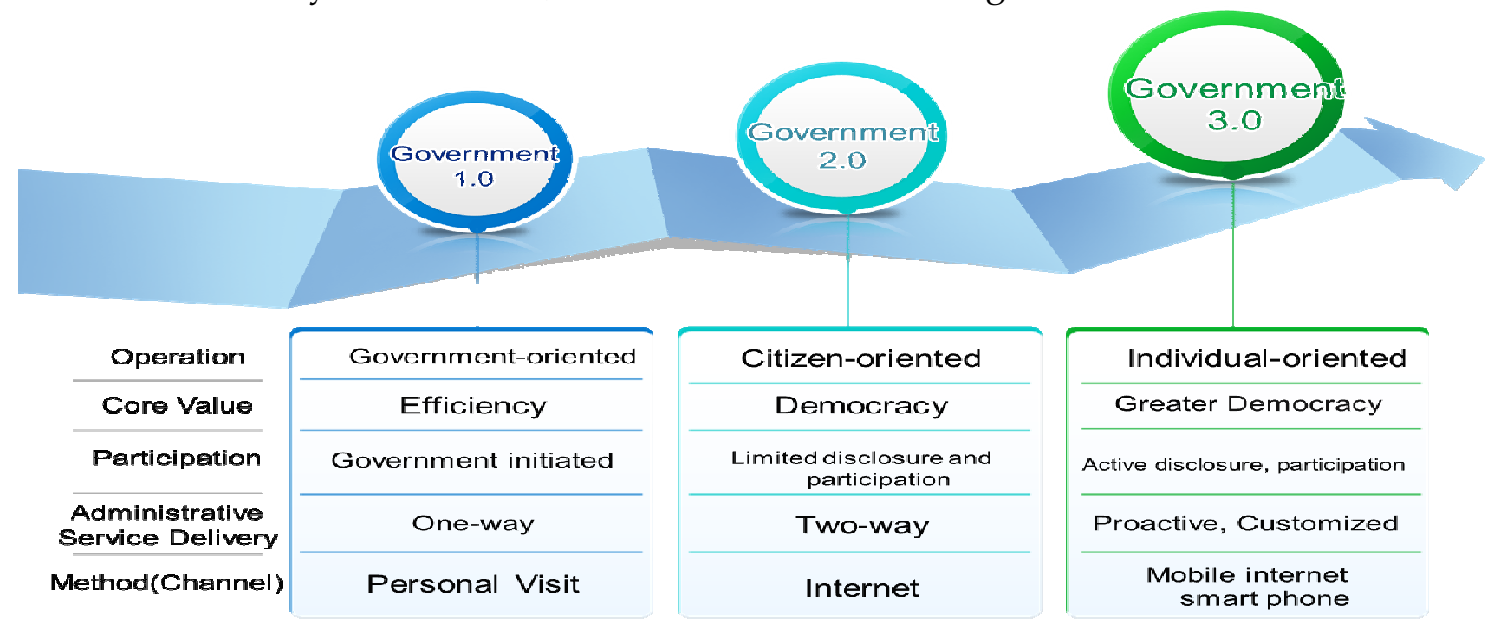

Figure 1. The evolution of Government in Korea

\subsection{Transparency}

Transparency means openness of decisions and actions. Put another way, it means a free flow of information about decisions and actions, from source to recipient. In other words, transparency is the open communication between citizens and governments. It is the effective knowledge with relevant information to citizens' needs. (Cerrillo-i-Martinez, 2011; Cuillier\& Piotrowski, 2009) Many deployed laws across the world are related to transparency like the right to information, open access of e-government information, or the use of ICT and the Internet to promote public information.

Here, we are interested in public sector transparency: flows of information about the decisions and actions taken by civil servants, politicians, judges, etc to various groups who would seek to hold them accountable-transparency means the use of ICTs to handle some or all of the transparencyrelated information flows.

In terms of the e-transparency, we need to consider publication which is just providing basic information about a particular area of government, transaction which is automating some public sector process and reporting on that process, reporting which is providing specific details of public sector decisions and actions, openness which is allowing users to compare public servant performance against pre-set benchmarks, and accountability which is allowing users some mechanism of control over public servants.

\subsection{Competency}

Competencies required for an e-government cover three things skills, knowledge and attitudes. All three of these must be addressed in planning the e-government project. Development of skills and knowledge can be undertaken through relatively straightforward training. Training to change attitudes is much harder but ultimately probably more important. Examples of attitude training could be including case study analyses of information systems failure and/or best practice, role-play exercises to highlight the gap between users and IT staff, group-forming activities for key stakeholders, and demonstrations of functioning information systems to highlight system benefits. follows.

In many contexts, the needed competencies can be divided into four main components as 
a) Systems Development Competencies

E-Government projects in developing countries have frequently had to rely on the import of external ICT personnel to develop new information systems. The indigenous information systems development capacity for e-governance must be strengthened, both within user organizations in the government and NGO sectors, and within private sector vendor organizations.

b) Project \& Change Management Competencies

The public sector particularly has been poor at managing e-government projects and at managing change. That capacity needs to be strengthened. E-government project managers particularly need help with managing the human components of projects and change.

c) Intelligent Customer Competencies

Public sector organizations especially have been poor ICT customers, unable to raise the finance for projects, unable to specify their needs, unable to manage the procurement process, and unable to manage vendors. These capacities need to be addressed to change a client-vendor relationship that, to date, has been too combative, too corrupt or too vendor-driven.

d) Operational Competencies

The ability of the public sector and other governance-related organizations to operate and maintain e-government systems must also be strengthened. For almost all developing countries this will still initially include a need to build basic computer literacy skills within user communities.

\subsection{Service-Oriented Government}

E-government was popularized during the dot-com era in the 1990s. The emergence of ecommerce and $\mathrm{Y}_{2} \mathrm{~K}^{1}$ advanced e-government, as governments began to adopt the changes taking place in the private sector. E-government is defined in various ways. (Relyea \& Hogue, 2004; Seifert \& Relyea, 2004) Some definitions of e-government are limited as a unit of the government, while others are very broadly defined, with e-governance integrated throughout the government. World Bank defines e-government as "the use by government agencies of information technologies (such as Wide Area Networks, the Internet, and mobile computing) that have the ability to transform relations with citizens, businesses, and other arms of government." (Jeong \& Kim, 2003; Kushchu \& Kuscu, 2003; Trimi \& Sheng, 2008) These technologies can serve a variety of different ends: better delivery of government services to citizens, improved interactions with business and industry, citizen empowerment through access to information, or more efficient government management. (Gronlund \& Horan, 2005; Reddick, 2005; Tian \&Tianfield, 2003) The resulting benefits can be less corruption, increased transparency, greater convenience, revenue growth, and cost reductions." (Definition of E-government, World Bank ${ }^{2}$ )

E-government is a transformation of government processes, transactions, and policy making and implementation that are efficiently carried out through information and communication technologies to provide better and efficient services to the citizens while reducing waste and corruption and increasing accountability, transparency, and trust. Furthermore, it is about creating an one-to-one relationship with the government in which citizens are empowered to take part in the democratic process and policy making.

E-government is increasingly being implemented in all areas of government administration at both the local, regional and national levels, increasing efficiency and transparency and bringing convenience and safety to citizens' lives, and consequently improving the quality of life (Fountain, 2001; Mulgan, 2000; Northrup \& Thorson, 2003). While it was initially promoted as a means of

\footnotetext{
${ }^{1}$ The total cost of $\mathrm{Y} 2 \mathrm{~K}$ was "revised to $\$ 1$ trillion or more. Reuters reported Jeffery Boonmee, founder and president of Bicom Link, as saying Y2K is now a \$3 trillion global industry, and that in the United States alone, the market for $\mathrm{Y} 2 \mathrm{~K}$ solutions is worth about $\$ 800$ billion." (The True Cost of $\mathrm{Y} 2 \mathrm{~K}$, Smart Computing, August 1999, Vol.7, Issue 8) 2http://go.worldbank.org/M1JHE0Z280, May 2012
} 
improving internal management efficiency in public administration, e-government is increasingly considered an important measure for enhancing citizen access to government services and expediting the delivery of services to citizens (Morris \& Moon, 2005; Streib \& Navarro, 2006). Egovernment is used to enhance citizens' access to government as much as government's access to citizens using current network technologies. (Irani et al., 2006; Premkumar et al., 2006; Heeks and Bailur, 2007; Seifert and Chung, 2008)

\section{Government Challenge: Korean Government 3.0}

As a leading country in ICT, Korean government is evolving their e-government structure as well as services. Korea's e-Government is transforming into citizen friendly services. Government 3.0 is a new paradigm for government operation. It aims to provide customized services for individual citizens and support more job creation by opening and sharing public information among government agencies and municipalities as well as removing the barriers in the government. (Song, 2014)

\subsection{Transparent Government}

With a Web 2.0, government focus on distributing government information previously unavailable to the citizens, either by intention or through neglect. In some cases, the interest is in enabling citizens to use this information as a political tool for transparency. When information and data about government actions and decisions are accessible, citizens can more effectively participate in decision making. They can also, at least in theory, assess the efficiency and effectiveness of government actions, and hold them accountable for their performance; a condition that is reciprocally expected to improve government performance. Such information is also a key to controlling corruption, since the right kind of information enables watchdog citizens and civil society organisations to track budget disbursements and expenditures.

Transparency is a public request by all parties involved in e-government. Many e-government systems are claimed to improve transparency and public entities efficiency like the Korean procurement services and On-Nara business process system. They are doing many efforts to improve transparency of e-government.

The Korean government discloses public information closely related to citizens 'lives. It also aims to vitalize public-private governance and establish foundations to create jobs and realize the creative economy.

To empowering people's right to know through information disclosure, Korean government listens to citizens' voice on what information they need to know and discloses public information held by central government ministries, municipalities and public agencies. Once public documents are approved, the original text disclosure system instantly discloses them without request, save for personal information and other confidentialities. The Korean government collectively discloses public information on the online information disclosure portal (open.go.kr) for easy access.

To enhancing the private sector's use of public data, Korean government are developing a government-wide public data disclosure roadmap and disclose $60 \%$ types of public data by 2017 ., it will select promising businesses in 15strategic fields that face strong demands from the private sector, such as transportation, patent, and employment, and help commercialize their business to create jobs.

To strengthening public-private partnerships and collaborations, Korean government increasingly involves experts and those who are directly affected by public policies in government administration through on-site visits and online policy debates. Citizens can suggest ideas and present complaints anytime, anywhere through various channels including telephone, text messages, social network services (SNS), and civil proposal service on the people's online portal (epeople.go.kr). Major policy issues and tasks are brought to thee-people portal for open discussions. 


\subsection{Competent Government}

The Korean government removes barriers among government agencies to strengthen sharing and interconnection of information, maximizes work efficiency through digital collaborations, and upgrades the quality of public administration and citizens' lives using big data.

To removing barriers in the government, Korean government will establish a problem-solving oriented approach to identify solutions for state affairs. It will establish a culture that encourages onthe-ground collaboration by resolving field problems where various ministries and agencies are involved and improving service delivery systems.

To remove barriers among organizations and improve citizens' convenience, government ministries and agencies swill share information with one another and integrate their systems. Korean government will increase personnel exchanges among central government ministries, between the central and local governments, and between the government and the private sector, thereby expanding an open government operation system.

To improving communication and collaboration among government agencies, the integrated communication system offers collaborative project management, report sharing, and messenger functions, thereby strengthening communication and collaboration among organizations indifferent locations. Korean government actively promotes videoconferences to reform its meeting practice and offers more smart work centres to improve administrative efficiency.

To enhancing rationality in administration with the use of Big Data, Korean government makes better use of various for most big data in public administration, thereby developing scientific, proactive policies and providing customized services. It will also establish a government-wide support system for predictive data analysis and advance identification of changes and risk factors.

\subsection{Service-oriented Government}

Engaging citizens in public governance has not only an intrinsic value in terms of deepening democracy, but it can also be instrumental in enhancing governments' capacity to deliver quality education services, promote gender equality and empowerment in public administration and society at large, deliver health services which can help reduce child mortality, improve maternal health, as well as eradicate disease, and promote a sustainable environment.

Implementing effective service and engaging citizens to take a more active role in development and in decisions that affect their lives poses.

The Korean government places citizens at the heart of all public services. It provides individual citizens with public services customized to their characteristics and life cycles. The Korean government also uses new information technology to realize whole new administrative services in the fields of disaster management, environment, and security.

In terms of the integrated provision of customized services, each government agency selects priority policies and services that are most requested by citizens and provides customized services. The government classifies its services by type of beneficiaries including childbirth, upbringing, the disabled and the elderly, and provides customized services.

Korean government provides integrated information and services related to citizen's life events such as moving and death. The civil service portal "Minwon 24" is designed to provide various types of information closely associated with citizens' lives, such as administrative penalties and refunds.

To enhance one-stop services for businesses, Korean government will establish an integrated system for SME support and manage track records of SME support projects of central and local governments in a systematic manner. Local governments will establish the one-stop permit processing system for businesses, and simplify approval processes for start-ups and businesses.

To improving access to services for the information poor, Korean government will improve the service delivery system and accessibility for vulnerable groups to minimize blind spots in public services. Text-to-speech conversion of civil petitions, improving web accessibility of the disabled, providing ICT aids. 
The government will also take advantage of the nationwide coverage of postmen networks, thereby enhancing civil affair and welfare services for vulnerable groups in rural areas, such as elderly living alone.

\section{Concluding Remarks}

The role of ICTs has dramatically changed over the past decade. Even in the private sector, until the mid-1990s, ICTs were commonly considered as corporate expenses with limited return on investments (ROIs). Governments had more passive approaches to adopting ICTs, often lagging behind the private sector. There was also typically lack of a legislative framework for e-government, largely due to ignorance or unwillingness to adopt transparency and accountability. Many global organizations define e-government in transitional terms as stages or phases. This implies that egovernment is an evolutionary progress. However, as we have seen in the private sector, with new ICTs, it is not always necessary to go through the same stages that others have gone through.

As a response to these challenges, Korean government is attempting to revitalize their public administration, make it more proactive, more efficient, more accountable, more service-oriented and closer to the people. To accomplish this transformation, governments are introducing innovations in their organizational structure, practices, capacities, and how they mobilize, deploy and utilize the human, material, information, technological and financial resources for service delivery to remote, disadvantaged and challenged people.

\section{Reference}

Cerrillo-i-Martínez, A., 2011. "The regulation of diffusion of public sector information bioelectronic means: Lessons from the Spanish regulation". Government Information Quarterly, Vol. 28, pp. 188-199.

Cuillier, D. \& Piotrowski, S., 2009. "Internet information-seeking and its relation to support for access to government records". Government Information Quarterly, Vol. 26, pp.441-449.

Fountain, J., 2001. "Building the virtual state: Information technology and institutional change Washington". DC7: Brookings Institution Press.

Gronlund, A. and Horan, T., 2005. "Introducing e-gov: History, definitions and issues". Communications of the Association for Information Systems, Vol. 15.

Heeks, R. and Bailur, S., 2007. "Analysing e-government research: Perspectives, philosophies, theories, methods, and practice". Government Information Quarterly, Vol. 24.

Irani, Z., Love, P., and Montazemi, A., 2006. "Call for papers: Special issue on e-government: Past, present and future". European Journal of Information Systems.

Jeong, K. and Kim, H., 2003. "After the introduction of the government portal services: Evolution into the m-government initiatives". In Proceedings of the ICA 37th Conference.

Kushchu, I. and Kuscu, H., 2003. "From E-government to M-government: Facing the Inevitable." The 3rd European Conference on e-Government.

Lee S., Tang X. and Trimi S., 2005. "Current practices of leading e-government countries". Communications of the ACM, Vol. 48, No. 10.

Morris, D. F. and Moon, M. J., 2005. “Advancing E-Government at the grassroots: Tortoise or hare?" Public Administration Review, 65(1), 64-75.

Mulgan, R., 2000. “Accountability: An ever-expanding concept?" Public Administration, 78(3), 55-73.

Northrup, T. A. and Thorson, S. J., 2003. "The Web of governance and democratic accountability." Proceedings of the 36th Annual Hawaii International Conference on System Sciences.

Premkumar, G., Ho, A. and Chakraborty, P., 2006. "E-government evolution: an evaluation of local online services". International Journal of Electronic Business, Vol. 4, No. 2.

Reddick, C., 2005. "Citizen interaction with e-government: From the streets to servers?". Government Information Quarterly. 22. 
Relyea, H. C., \& Hogue, H. B., 2004. A brief history of the emergence of digital government in the United, In A. Pavlichev \& G. D. Garson (Eds.), Digital government: Principles and best practices (pp. 16-33), Hershey, PA: Idea Group Publishing.

Seifert, J. W., and Relyea, H. C., 2004. "Considering e-government from the federal perspective: An evolving concept, a developing practice". Journal of E-Government, 1(1): 7-15.

Seifter, J. and Chung, J., 2008. "Using e-Government to Reinforce Government-Citizen Relationships". Social Science Computer Reviews.

Song, In Kuk, 2014. “Emerging Internet Technology \& Service toward Korean Government 3.0”. KSII Transactions on Internet and Information Systems, Vol 8, No 2.

Streib, G. and Navarro, I., 2006. "Citizen demand for interactive E-Government: The case of Georgia consumer services". American Review of Public Administration, 36(3), 288-300.

The transformation of government, World Economic Forum,

http://www.weforum.org/news/future-government-lessons-learned-around-world

Tian, J. and Tianfield, H. “Some Perspectives of e-Government. In F. Bannister, \& D. Remenyi (Eds.) 3rd Euripean conference on e-Government, 2003.

Trimi, S. and Sheng, H., 2008. "Emerging Trends in m-government". Communications of the ACM, Vol 51, No. 5. 